\title{
PERAN PENDIDIKAN ISLAM DALAM PENGEMBANGAN KARAKTER
}

\author{
Nama : Dewi Nur Lailatin Nisfiyah \\ Institut Pesantren KH Abdul Chalim Mojokerto \\ Email : Dewinurlailatin02@gmail.com
}

\section{Pendahuluan}

Dari perkembangan zaman itu sendiri, kita tau bahwa banyak terjadi permasalahan-permasalahan yang dihadapi bangsa Indonesia. Dilihat dari permasalahan politik yang saling membenarkan anggotanya sendiri dan juga banyaknya kasus korupsi, lalu dari segi ekonomi yang masih belum stabilnya dan merata, dan kalau dilihat dari segi pendidikan yang masih dirasa belum sistemnya kurang efektif dan efisien. Jika terus dibiarkan maka permasalahan tersebut akan tertumpuk dan malah menimbulkan permasalahan baru. Untuk penyelesaiannya, tentunya kita harus saling berpartisipasi dalam menyikapinya. Membutuhkan kerja sama baik dari kalangan pemerintah maupun masyarakat. Dari kasus diatas, kita melihat dari kasus pendidikan dimana dunia pendidikan pada dasarnya merupakan komponen penting atau pondasi awal sebelum menyelesaiakan kasus-kasus lainnya.

Pendidikan merupakan bagian dari kegiatan kehidupan bermasyarakat dan berbangsa. Oleh sebab itu, kegiatan pendidikan merupakan perwujudan dari cita-cita bangsa. Terjadinya penurunan moral pada peserta didik merupakan salah satu kendala keberlangsungan sistem pendidikan atau bisa dikatakan fenomena ini salah satu perwujudan penyebab gagalnya sistem pendidikan ${ }^{1}$. Dari sekian banyak materi yang diajarkan di lembaga pendidikan, semua ranahnya diharapkan bisa menciptakan karakter yang baik untuk peserta $\operatorname{didik}^{2}$. Dalam hal ini sekolah khususnya pembelajaran pendidikan agama islam memiliki peran yang besar dalam pengembangan karakter peserta didik. Kita tau bahwa, pendidikan agama islam diharapkan bisa melahirkan masyarakat yang terdidik, berakhlaqul karimah, dan

\footnotetext{
${ }^{1}$ Ali Mudlofir, “Pendidikan Karakter: Konsep Dan Aktualisasinya Dalam Sistem Pendidikan Islam," Nadwa: Jurnal Pendidikan Islam 7, no. 2 (22 Maret 2016): 229-46, https://doi.org/10.21580/nw.2013.7.2.560; Lian G. Otaya, "Pendidikan Karakter Berbasis Nilai," Nadwa 8, no. 1 (2014): 75-94.

${ }^{2}$ Nurhadi Nurhadi, "Concept Of The Mosque As An Education Means Faith And The End Of Children In The Modern Era," Nazhruna: Jurnal Pendidikan Islam 2, no. 2 (11 Agustus 2019): 190-208, https://doi.org/10.31538/nzh.v2i2.333.
} 
mampu meningkatkan kesadaran masyarakat untuk hidup secara harmonis dan toleran $^{3}$.

Dalam dunia pendidikan, kita tau bahwa lebih mengedepankan aspek pengembangan otak kiri ( kognitif) tetapi kurang memperhatikan dari aspek pengembangan otak kanan ( afektif ). Dari kasus diatas menimbulkan generasi yang hanya memiliki intelektual yang tinggi namun kurangnya rasa empati atau karakter itu sendiri. Sebagaimana contoh kasus para koruptor itu yang melakukan adalah para pemimpin seperti bupati, wali kota, DPR, kepala desa. Tentunya kita tau mereka adalah sosok yang berintelektual. Oleh karena itu, butuh adanya perubahan dari sistem pendidikan itu sendiri. Apalagi mengenai pendidikan agama islam yang sangat penting atau memiliki nilai-nilai perbaikan karakter. Jika nilai tersebut bisa dijalankan secara seimbang, maka bisa jadi menciptakan generasi yang awalnya goyah dengan lembaran rupiah menjadi pekerja keras dengan hasil dari usahanya sendiri, menciptakan generasi yang bermental kuat, generasi yang mau berkorban demi kepentingan umum bukan kepentingan pribadi dan tertunya generasi yang berakhlaqul karimah $^{4}$.

Pendidikan agama islam jika dilaksanakan dan terkonsep dengan baik maka capaian-capain akan cepat tercapai. Jika secara sistem baik, pendidikan agama islam sangat mempengaruhi siswa dalam pengembangan karakter. Karena pendidikan agama bisa menjadi landasan hidup dan hukum setiap individu dalam melakukan sesuatu. Meski di indonesia ini telah menggunakan kurikulum 2013 yang sudah jelas dalam setiap mata pelajaran yang diberikan selalu ada nilai pendidikan karakternya , namun yang selalu dipandang khusus ialah dari segi pengajaran pendidikan agama islamnya. Jika setiap mata pelajaran seperti matematika, IPA, atau IPS hanya mengembangkan ranah kognitifnya, sedangkan pendidikan agama islam akan menyeimbangkanya dengan mengarahkan pada ranah afektif dengan cara pendalaman nilai moral yang ditanamkan pada setiap individu.

\footnotetext{
${ }^{3}$ Muhammad Anas Ma'arif dan Muhammad Husnur Rofiq, "The Model of Character Teacher: Phenomenology at Daruttaqwa Gresik Islamic Boarding School," ATTARBIYAH: Journal of Islamic Culture and Education 3, no. 2 (2 Januari 2019): 131-52, https://doi.org/10.18326/attarbiyah.v3i2.131-152.

${ }^{4}$ Muhammad Nur Hakim dan Fitriyani Dwi Rahayu, "Pembelajaran Saintifik Berbasis Pengembangan Karakter," Nazhruna: Jurnal Pendidikan Islam 2, no. 1 (24 Februari 2019): 1-27, https://doi.org/10.31538/nzh.v2i1.148.
} 


\section{Pembahasan}

\section{Definisi Pendidikan Agama Islam}

Pendidikan memiliki peran sentral dalam pembinaan kepribadian bangsa. Di Indonesia, definisi pendidikan dapat dilihat pada Pasal 1 Ayat 1 Undang-Undang Nomor 20 Tahun 2003 tentang Sistem Pendidikan Nasional, yakni : pendidikan adalah usaha sadar dan terencana untuk mewujudkan suasana belajar dan proses pembelajaran agar peserta didik secara aktif mengembangkan potensi dirinya untuk memiliki kekuatan spiritual keagamaan, pengendalian diri, kepribadian, kecerdasan, akhlak mulia, serta keterampilan yang diperlukan dirinya, masyarakat, bangsa dan negara. 5

Jika mengacu pada pasal diatas, pendidikan di Indonesia tidak hanya mencakup dari aspek kognitif saja, melainkan bagaimana dalam proses belajar dan mengajar dalam pendidikan tersebut menciptakan suasana yang mencetak potensi siswa yang cerdas namun memiliki kepribadain meliputi spiritualnya, pengendalian dirinya, serta akhlak mulia. Kita tau sendiri bahwa modal tersebut sangat dibutuhkan baik untuk siswa itu secara pribadi, juga sangat dibutuhkan dalam hidup secara bermasyarakat. Jika pendidikan tersebut mampu mencetak potensi siswa yang demikian maka sudah membuktikan bahwa maju nya sumber daya manusia negara tersebut ${ }^{6}$

Dalam menciptakan kemajuan dalam dunia pendidikan, tentunya banyak sekali aspekaspek yang harus diperhatikan. Mulai dari guru, kurikulum, materi, dan lain sebagainya. Dari segi lingkungan pun sangat mempengaruhi baik itu lingkungan sekolah maupun masyarakatnya. Dari semua aspek tersebut, harus tercipta kesinambungan saling mendukung satu sama lain agar nantinya bisa terwujud tujuan pendidikan tersebut.

Pendidikan juga berlangsung di lingkungan keluarga. Keluarga merupakan pusat pendidikan yang pertama dan utama yang dialami oleh siswa. Pada hakikatnya keluarga itu adalah semata-mata pusat pendidikan, meskipun kadang berlangsung sangat sederhana dan tanpa disadari bahwa keluarga memiliki andil yang besar dalam pendidikan anak. Dalam keluarga, orang tua memiliki peranan dan tanggung jawab yang sangat besar dalam mendidik, membimbing, dan mengasuh anak. Pengasuhan

\footnotetext{
${ }^{5}$ Erma Pawitasari, Endin Mujahidin, dan Nanang Fattah, "Pendidikan Karakter Bangsa Dalam Perspektif Islam (Studi Kritis Terhadap Konsep Pendidikan Karakter Kementerian Pendidikan \& Kebudayaan)" 4, no. 1 (2015): 2252-5793.

${ }^{6}$ Muhammad Ridwan, “Konsep Tarbiyah, Ta'lim Dan Ta'dib Dalam Al-Qur'an," Nazhruna: Jurnal Pendidikan Islam 1, no. 1 (16 Agustus 2018): 35-57, https://doi.org/10.31538/nzh.v1i1.41.
} 
dari orang tua terhadap anak memegang peranan besar dalam perkembangan anak pada masa mendatang baik itu perkembangan fisik maupun perkembangan psikisnya.

Pendidikan dari keluarga adalah modal atau pondasi anak sebelum ia memulai belajar ke jenjang yang lebih tinggi. Dari sini peran orang tua lah yang sangat mempengaruhi. Orang tua mempunyai tanggung jawab untuk mendidik dan membimbing anak sehingga anak mampu mengatasi problematika diluar. Karena sebelum ia belajar ke jenjang yang lebih tinggi, terlebih dahulu orang tua harus mampu mengajarkan anak bagaimana menyikapi persoalan-persoalan dan orang tua harus sangat memperhatikan perkembangan anaknya. Untuk pembekalan utama, dirasa penting untuk mengajarkan anak yaitu pendidikan agama islam. Karena pendidikan agama adalah pondasi awal dalam mencetak kepribadian. Pendidikan agama islam juga salah satu penunjang keberhasilan sebuah pendidikan.

Dalam islam, nabi Muhammad pada awal diutusnya turun ayat 1-5 surat Al-Alaq. Dimana surat ini memberikan perintah tentang pengajaran. Secara tidak langsung dalam pengajaran pertama dalam islam diawali dengan pengajaran dan pendidikan sebagai pondasi utama setelah iman, islam, dan ihsan. Adapun arti ayatnya : "Bacalah dengan (menyebut) nama tuhanmu yang menciptakan. Dia telah menciptakan manusia dari segumpal darah. Bacalah, dan Tuhanmulah yang paling pemurah. Yang mengajar (manusia) dengan perantaraan kalam. Dia mengajarkan kepada manusia yang tidak diketahuinya"7

Jika kita fahami melalui isyarat ayat diatas ada beberapa indikator yang bisa disimpulkan antara lain : pertama,manusia sebagai subyek dimana manusia sebagai pembaca,pemerhati, perenung, peneliti atas asas niat yang baik tak lupa dengan menyebut nama tuhan. Kedua, menjadi manusia yang sempurna harus memperhatikan melalui obyek apa yang dibaca, diperhatikan, serta direnungkan. Ketiga, dalam kegiatan membaca tentunya memperhatikan media apa yang dipakai dan lain-lain. Keempat, manusia dalam potensi dan motivasinya. ${ }^{8}$

Dalam pembelajaran pendidikan agama islam, kita tau sendiri jika menjadi umat yang beragama menyakini ayat yang pertama kali turun ialah perintah iqro' yang artinya bacalah, belajarlah, atau berpikirlah. Pergunakan akal untuk menggali ilmu

\footnotetext{
${ }^{7}$ H Abdul Rahman dan Kata Kunci, "PENDIDIKAN AGAMA ISLAM DAN PENDIDIKAN ISLAM TINJAUAN EPISTEMOLOGI DAN ISI - MATERI” 8, no. 1 (2012): 2053-59.

${ }^{8}$ Ibid.
} 
pengetahuan. Akal adalah makna dari otak yang dimanfaatkan untuk berpikir dan ilmu pengetahuan yang dapat menghantarkan martabat dan karakter bangsa hanya bisa dikembangkan oleh akal ( otak yang dioperasionalisasikan). Dari sini jelas bahwa memang untuk membangun karakter, watak martabat bangsa harus dimulai dari pendidikan. 9

Pendidikan agama islam secara sederhana dapat dikatakan sebagai pendidikan yang dipahami, dikembangkan, dan diajarkan dalam nilai-nilai dasar yang terkandung dalam sumber dasar islam yaitu Al-Quran dan As-Sunnah.

Dalam bahasa arab terdapat tiga kata yang menunjukan arti pendidikan yaitu tarbiyah, ta'lim, dan ta'dib. Menurut mu'jam bahasa arab kata al-tarbiyah memiliki tiga kebahasaan, yaitu :

1. Robba yarbu tarbiyah yang memiliki arti tambah (zad) dan berkembang (nama) artinya pendidikan merupakan proses menumbuhkan dan mengembangkan apa yang ada pada diri peserta didik baik secara fisik, psikis, sosial maupun spiritual.

2. Robba yurbi tarbiyah yang memiliki arti tumbuh (nasya'a) dan menjadi besar atau dewasa (tarara'a) artinya pendidikan merupakan usaha untuk menumbuhkan dan mendewasakan peserta didik secara fisik, psikis, sosial maupun spiritual.

3. Rabba yarubbu tarbiyah yang memiliki arti memperbaiki (ashlaha) menguasai urusan, memelihara, merawat, menunaikan, memberi makan, mengasuh, memiliki, mengatur dan menjaga kelestarian maupun eksistensinya. Artinya pendidikan merupakan usaha untuk memelihara, mengasuh, merawat, memperbaiki, dan mengatur kehidupan peserta didik agar lebih baik dalam kehidupannya.

Pendidikan agama islam dapat diartikan sebuah usaha sadar dimana usaha yang berkelanjutan mengembangkan potensi ras, agama, menanamkan sifat dan memberikan kecakapan sesuai dengan tujuan pendidikan islam. Dari pengertian pendidikan agama islam tersebut terlihat penekanan pendidikan islam pada bimbingan bukan pengajaran yang mengandung tautan pemikiran kepada pihak pelaksana pendidikan yakni pendidik (guru) dengan bimbingan sesuai ajaran-ajaran islam, maka

\footnotetext{
${ }^{9}$ Rosniati Hakim, "Pembentukan Karakter Peserta Didik Melalui Pendidikan Berbasis Al-Quran," Jurnal Pendidikan Karakter, no. 2 (2015): 123-36.
} 
peserta didik mempunyai ruang gerak yang cukup luas untuk membenarkan segala potensi yang dimiliki.

Tujuan pendidikan agama islam adalah suatu perubahan yang ingin dicapai agar berubah menjadi lebih baik lagi tentunya perubahan tersebut didasarkan pada perilaku yang dilandasi ajaran Al-Quran dan As-Sunnah. Dilihat dari diutusnya Nabi Muhammad adalah untuk memperbaiki akhlak. Karena akhlak atau moral merupakan jiwa pendidikan islam tanpa mengabaikan jasmani, akal, dan ilmu praktis.

Oleh karena itu, peran pendidikan agama islam merupakan salah satu perantara pendidikan karakter. Dimana pendidikan karakter selain menjadi bagian dari proses pembentukan akhlak anak bangsa, diharapkan mampu menjadi pondasi utama dalam meningkatkan derajat dan martabat bangsa Indonesia. Dalam kurikulum sekarang yang diberlakukan oleh pemerintah, penilaian dalam segi perilaku siswa juga menjadi nilai tambah, oleh kementrian pendidikan dan kebudayaan sendiri pun menjadikan pendidikan karakter menjadi fokus pendidikan diseluruh jenjang pendidikan yang dibinanya. Pembentukan karakter itu, dimulai dari fitrah yang diberikan tuhan yang kemudian dikembangkan melalui pembelajaran sehingga membentuk jati diri dan perilaku. Adapun proses pembelajaran itu sendiri memerlukan partisipasi dari berbagai kalangan, baik itu orang tua, guru, teman, atau yang lain. Proses pembelajaran juga dapat dipengaruhi dari lingkungan baik disekolah maupun lingkungan masyarakat. Atau bisa dikatakan ada dua faktor yaitu faktor internal dan faktor eksternal. Dengan itu, baik dari faktor internal maupun eksternal harus memiliki pendisiplinan dan kebiasaan mengenai karakter yang akan dibentuk. Para pemimpin dan tokoh masyarakat juga perlu memberikan sumbangsinya untuk memberikan contoh keteladanan mengenai karakter yang akan dibentuk tersebut. Karena islam sangat memperhatikan dalam segi pendidikan, dikhususkan adanya sebuah proses dimana ketika anak dari lahir beserta asal tempatnya sampai kehidupan individu dan bermasyarakatnya terlebih pribadi individu tersebut. Dan orang-orang yang terlibat dalam pembinaan kepribadian dan pendidikan anak adalah orang tua, masyarakat, dan sekolah. ${ }^{10}$

Pendidikan agama islam yang biasa diterapkan dirasa hanya memberikan pengetahuan kognitif semata, tanpa menerapkan bahwa maksud dari mempelajari pendidikan

\footnotetext{
${ }^{10}$ Muhammad Abd. Alim, Al-Tarbiyah wa al-Tanmiyah.. fi al-islam. (Riyadh: KSA, 1992)
} 
agama islam yaitu untuk memperbaiki seseorang dari segi karakternya. Karena dalam pendidikan agama islam tak hanya mempelajari mengenai hukum-hukum syar'i saja namun juga banyak nilai-nilai moral/akhlak. Jadi dalam mengaplikasikan guru seharusnya tak hanya menggunakan metode hafalan atau ceramah saja namun juga harus bisa memberikan kesan yang mendalam sehingga tak hanya sekedar dipelajari namun juga bisa diterapkan dalam kehidupan sehari-hari.

Dalam Undang-Undang No. 14 Tahun 2005 tentang Guru dan Dosen dijelaskan syarat-syarat untuk menjadi guru yaitu seseorang harus memiliki ijazah, sehat jasmani dan rohani, bertaqwa kepada Tuhan Yang Maha Esa, berkelakuan baik, bertanggung jawab, dan berjiwa nasional.

Dilihat dari pasal diatas peran guru sangatlah berpengaruh. Karena untuk menjadi guru yang ideal dan profesional harus memiliki potensi dari segi akademik maupun non akademiknya. Seorang guru harus memiliki skill yang hebat serta pengontrolan diri yang baik. Guru harus memiliki kelakuan yang baik dimana modal tersebut sangat diperlukan untuk memberi contoh kepada anak didiknya, guru harus memiliki rasa tanggung jawab karena dalam proses mengajar guru dituntut bisa mendidik sekaligus membimbing anak didiknya tak hanya sekedar mengajar semata. Sikap baik seorang guru juga bisa dicerminkan melalui sikap adilnya pada semua siswa, percaya dan suka kepada anak didiknya, bersikap sabar dan rela berkorban untuk kepentingan pembelajaran, bersikap baik tak hanya pada murid tapi juga kepada sesama gur dan masyarakat umum. Serta yang lebih penting yaitu menguasai materi apa yang akan diajarkan. Jika guru dapat memenuhi kriteria diatas, maka dijamin suasana pembelajaran akan lebih kondusif sehingga bisa mempengaruhi tingkah laku siswa yang kemungkinan bisa terbawa dalam kehidupan sehari-hari yang menyebabkan karakter pada siswa ${ }^{11}$.

Membangun karakter juga diperlihatkan dalam ajaran pendidikan agama islam yaitu dimana Nabi Muhammad SAW pertama kali diutus ialah untuk memperbaiki akhlak. Jadi penanaman pendidikan karakter bisa kita teladani dari kepribadian yang di contohkan Rosulullah. Jika kita artikan dalam bahasa arab Rosulullah adalah uswatun khasanah yang pantas jadi teladan. Secara psikologis, manusia butuh teladan baik dari

\footnotetext{
${ }^{11}$ Mohammad Ali, “Penggunaan Professional Development School Dalam Praktik Kependidikan Untuk Mengembangkan Profesionalisme Calon Guru," Jurnal IImu Pendidikan 7, no. 3 (5 Februari 2016), https://doi.org/10.17977/jip.v7i3.666.
} 
tingkat anak-anak, remaja maupun dewasa agar jadi panutan dalam berbicara, bergaul, tingkah laku, bahkan gaya hidup sehari-hari. Oleh karena itu, dalam pembentukan karakter butuh pendalaman pendidikan agama islam yang tak hanya difahami secara teoritis namun dapat di implementasikan dalam kehidupan sehari-hari.

\section{Pendidikan Karakter}

Untuk saat ini, pembahasan tentang pendidikan karakter sangatlah banyak. Karena belakangan ini pendidikan karakter jadi pembahasan utama dikalangan masyarakat Indonesia. Terlebih dikalangan akademisi. Jika untuk saat ini masyarakat kita cenderung mengabaikan nilai-nilai karakter . Adapun nilai - nilai karakter seperti religius, santun, jujur, dan gotong royong untuk saat ini bisa tergeser dengan arus budaya barat yang cenderung individualistik, hedonistik, dan materialistik sehingga karakter yang seharusnya jadi ciri khas kita bisa dianggap tidak penting jika hal itu bertentangan dengan tujuan yang ingin diperoleh. ${ }^{12}$ Nilai karakter merupakan perilaku yang muncul atau terlihat pada siswa dalam berinteraksi sebagai makhluk sosial. Nilai karakter ini terjadi dilingkungan keluarga, lingkungan masyarakat ditempat tinggalnya, lingkungan pergaulannya dengan teman sebaya, serta lingkungan sekolah tempat siswa banyak menghabiskan waktunya untuk belajar. Nilai karakter yang dimaksud adalah karakter religius, jujur, toleransi, disiplin, kerja keras, kreatif, mandiri, demokratis, rasa ingin tahu, semangat kebangsaan, cinta tanah air, menghargai prestasi, bersahabat dan komunikatif, cinta damai, gemar membaca, peduli lingkungan, peduli sosial, dan tanggung jawab. ${ }^{13}$

Karakter jika dalam pandangan islam sama halnya dengan akhlak. Akhlak dalam islam sama halnya dengan kepribadian. Dalam sebuah kepribadian mengenal tiga unsur antara lai $\mathrm{n}$ perilaku, sikap, dan pengetahuan. Dalam kepribadian kita membaginya dalam 2 bagian. Yang pertama yaitu kepribadian utuh dimana pengetahuan seseorang itu sinkron dengan sikapnya. Lalu yang kedua ialah kepribadian pecah dimana antara pengetahuan dan kepribadiannya tidak sinkron maksudnya orang tersebut memahami bahwa jujur adalah sikap yang baik dan tentu harus dijadikan sebuah kepribadian namun perilakunya sering tidak mencerminkan

\footnotetext{
${ }^{12}$ Doni Koesoema A, Pendidikan Karakter : Strategi Mendidik Anak di ZamanGlobal, (Jakarta:Grasindo, 2007), Cet. 1. H. 10

${ }^{13}$ Hanafi, "Manajemen Pendidikan Karakter siswa di Sekolah dasar,” 2017.
} 
apa yang dia benarkan sendiri, ini merupakan contoh kepribadian pecah (Split Personality). ${ }^{14}$

Pembentukan karakter dapat dilakukan dengan menggunakan keteladanan. Keteladanan berawal dari suatu peniruan antar manusia. Keteladanan dalam dunia pendidikan sering melekat pada seorang guru sebagai pendidik. Keteladanan dalam dunia pendidikan dapat diartikan sebagai perilaku dan sikap guru dan tenaga pendidik dilingkungan sekolah maupun luar sekolah yang dijadikan contoh oleh para siswanya (Kementerian Pendidikan Nasional, 2010).

Dalam mencetak karakter yang mulia dalam dunia pendidikan itu memiliki tiga aspek sasaran. Pertama, sasaran pengisian otak (transfer of knowledge). Disini yang paling ditekankan adalah mengisi kognitif peserta didik, mulai dari yang sederhana seperti menghafal hingga analisis. Kedua, mengisi hati melahirkan sikap positif (transfer of value), sasarannya menumbuhkan kecintaan kepada kebaikan dan membenci kejahatan. Ketiga, perbuatan (transfer of activity) timbul keinginan untuk melakukan yang baik dan menjauhi perilaku yang jelek. ${ }^{15}$

Melihat hal-hal yang mencerminkan menipisnya dan menurunya karakter peserta didik, perlu adanya pemahaman materi khususnya materi pendidikan agama islam. Karena kebanyakan peserta didik hanya memahaminya melalui teorinya saja dengan cara menghafal. Namun perlunya peserta didik tak hanya memahami secara teori saja melainkan bisa mengamalkan nilai karakternya untuk kehidupan sehari-hari.

\section{Pengembangan Karakter}

Menurut Azyumardi Azra untuk mengembangkan pendidikan karakter di sekolah, setidaknya melalui pendekatan melalui ${ }^{16}$ :

1. Pendekatan modelling atau axemplary.

Jika dalam bahasa arab nya disebut uswatrtun hasanah. Dalam penerapan pendekatan ini, seluruh lingkup anggota sekolah membiasakan lingkungan

\footnotetext{
${ }^{14}$ Abdul Majid dan Dian Andayani, Pendidikan Karakter Perspektif Islam, (Bandung: PT Remaja rosdakarya,

${ }^{15}$ Haidar Putra Daulay, Pendidikan Islam (Dalam Sistem Pendidikan Nasional di Indonesia), (Jakarta:Kencana Prenada Media Group,2004), hlm. 39.

${ }^{16}$ Zubaedi, Desain Pendidikan karakter, Konsepsi dan Aplikasinya dalam Pendidikan (Jakarta: Kencana Prenada, 2011).
} 
sekolah untuk hidup dan menerapkan nilai-nilai akhlak dan moral yang benar melalui suri tauladan. Disini peran guru sangatlah penting karena guru adalah panutan siswanya disekolah. Jika melalui pendekatan modelling atau axemplary guru harus menjadi uswatun hasanah agar siswa nya bisa mencontoh. Karena jika guru hanya sekedar memberikan perintah atau pelajaran semata tanpa pemberian contoh nyata, maka bisa saja siswa tak akan memperdulikannya. sehingga pembentukan karakter tersebut tak nampak.

2. Memberikan pemahaman kepada siswa dengan penjelasan dan mengklasifikasikan nilai-nilai yang baik dan mana nilai-nilai yang buruk. pemahaman tersebut perlu diberikan secara terus menerus kepada peserta didik. Terutama kepada peserta didik yang masih kecil setingkat TK atau MI/SD. Karena dalam tingkatan tersebut masih perlu bimbingan karena seusia mereka masih perlu pemahaman yang lebih. Jika sudah tingkatan SMP/SMA mereka sudah bisa mandiri dan lebih kepada pemberian contoh nyata, namun perlu juga pemahaman mengenai nilai-nilai tersebut karena dalam usia mereka ialah masa-masa puber dimana emosi masih belum stabil.

3. Menerapkan pendidikan berdasarkan karakter ( character based education ). Upaya penerapan pendekatan ini, bisa melalui memasukkan pendidikan karakter kedalam setiap mata pelajaran. Dan mungkin diterapkan pada pelajaran agama atau PPKN karna pelajaran ini sejalur apabila dimasukkan pendidikan karakter didalamnya. Tetapi bisa juga memungkinkan memasukkan pendidikan karakter kedalam mata pelajaran selain pelajaran agama dan PPKN. ${ }^{17}$

${ }^{17}$ Azyumardi Azra, Paradigma Baru Pendidikan Nasional, Rekonstruksi dan Demokratisasi ( Jakarta: PT Kompas Media Nusantara, 2002 ), hal. 187-186 


\section{REFERENSI}

Ali, Mohammad. "Penggunaan Professional Development School Dalam Praktik Kependidikan Untuk Mengembangkan Profesionalisme Calon Guru." Jurnal Ilmu Pendidikan 7, no. 3 (5 Februari 2016). https://doi.org/10.17977/jip.v7i3.666.

Hanafi. "Manajemen Pendidikan Karakter siswa di Sekolah dasar," 2017.

Ma'arif, Muhammad Anas, dan Muhammad Husnur Rofiq. "The Model of Character Teacher: Phenomenology at Daruttaqwa Gresik Islamic Boarding School." ATTARBIYAH: Journal of Islamic Culture and Education 3, no. 2 (2 Januari 2019): 131-52. https://doi.org/10.18326/attarbiyah.v3i2.131-152.

Mudlofir, Ali. "Pendidikan Karakter: Konsep Dan Aktualisasinya Dalam Sistem Pendidikan Islam." Nadwa: Jurnal Pendidikan Islam 7, no. 2 (22 Maret 2016): 229-46. https://doi.org/10.21580/nw.2013.7.2.560.

Nur Hakim, Muhammad, dan Fitriyani Dwi Rahayu. "Pembelajaran Saintifik Berbasis Pengembangan Karakter." Nazhruna: Jurnal Pendidikan Islam 2, no. 1 (24 Februari 2019): 1-27. https://doi.org/10.31538/nzh.v2i1.148.

Nurhadi, Nurhadi. "Concept Of The Mosque As An Education Means Faith And The End Of Children In The Modern Era." Nazhruna: Jurnal Pendidikan Islam 2, no. 2 (11 Agustus 2019): 190-208. https://doi.org/10.31538/nzh.v2i2.333.

Otaya, Lian G. "Pendidikan Karakter Berbasis Nilai." Nadwa 8, no. 1 (2014): 75-94.

Pawitasari, Erma, Endin Mujahidin, dan Nanang Fattah. "Pendidikan Karakter Bangsa Dalam Perspektif Islam (Studi Kritis Terhadap Konsep Pendidikan Karakter Kementerian Pendidikan \& Kebudayaan)" 4, no. 1 (2015): 2252-5793.

Rahman, H Abdul, dan Kata Kunci. "PENDIDIKAN AGAMA ISLAM DAN PENDIDIKAN ISLAM - TINJAUAN EPISTEMOLOGI DAN ISI - MATERI” 8, no. 1 (2012): 205359.

Ridwan, Muhammad. “Konsep Tarbiyah, Ta'lim Dan Ta'dib Dalam Al-Qur'an.” Nazhruna: Jurnal Pendidikan Islam 1, no. 1 (16 Agustus 2018): 35-57. https://doi.org/10.31538/nzh.v1i1.41.

Rosniati Hakim. "Pembentukan Karakter Peserta Didik Melalui Pendidikan Berbasis A1Quran." Jurnal Pendidikan Karakter, no. 2 (2015): 123-36.

Zubaedi. Desain Pendidikan karakter, Konsepsi dan Aplikasinya dalam Pendidikan. Jakarta: Kencana Prenada, 2011. 